\title{
A study of yaws among pygmies in Cameroon and Zaire
}

\author{
S. PAMPIGLIONE
}

Cattedra di Parassitologia, University of Bologna, Italy

AND

A. E. WILKINSON

V.D. Reference Laboratory, The London Hospital, London E.1

Surveys were carried out in the winters of 1969-70 and 1970-71 on groups of pygmies living in South Cameroon, the Bayaka and Badjelli, and in East Zaire, the Bambuti. They inhabit areas of primary rain forest with an environmental temperature of about $27^{\circ} \mathrm{C}$. and a nearly constant relative humidity of 95 per cent.

\section{Social conditions}

The pygmies are nomadic hunters and gatherers living in small groups of twenty to sixty persons. Their main food is the game they hunt, including all the forest fauna, which ranges from mice to elephants, wild fruits, tubers, vegetables, and tree honey. At certain times of the year they go to Bantu villages and work on the plantations, and are given food in return for their labour. The Bantu regard the pygmies as an inferior race and treat them as their subjects. This relationship seems to have existed for a long time, and is accepted by the pygmies; however they maintain

Received for publication September 9, 1974

Requests for reprints to Dr. A. E. Wilkinson, as above the right to leave if dissatisfied with their masters' treatment (Turnbull, 1965).

Disease is rife among the pygmy groups. In the Cameroon, intestinal parasites are very common (Pampiglione and Ricciardi, 1974): helminths are found in more than 90 per cent., and protozoa in about 60 per cent. Filariasis is also found (Dipetalonema perstans 48 per cent.; Loa loa 8 per cent). Vesical and intestinal schistosomiasis is rarely seen, but 33 per cent. of the groups studied had malarial parasites. Scabies, chigger infections, and cutaneous mycoses are common. A similar pattern of infestation is found in Zaire with the addition of infection with Onchocerca volvulus. Syphilis seems to be very rare among the pygmies and always of Bantu origin.

\section{Scope of the survey}

In the Cameroon, two areas were visited (Fig. 1); (a) two camps in the Sousprefecture of Lomie and (b) two camps in the Sousprefécture of Akom-deux. In Zaire, surveys were carried out at four camps in the Epulu area and one at Bafuakoa; these camps are in the district of Bunia,

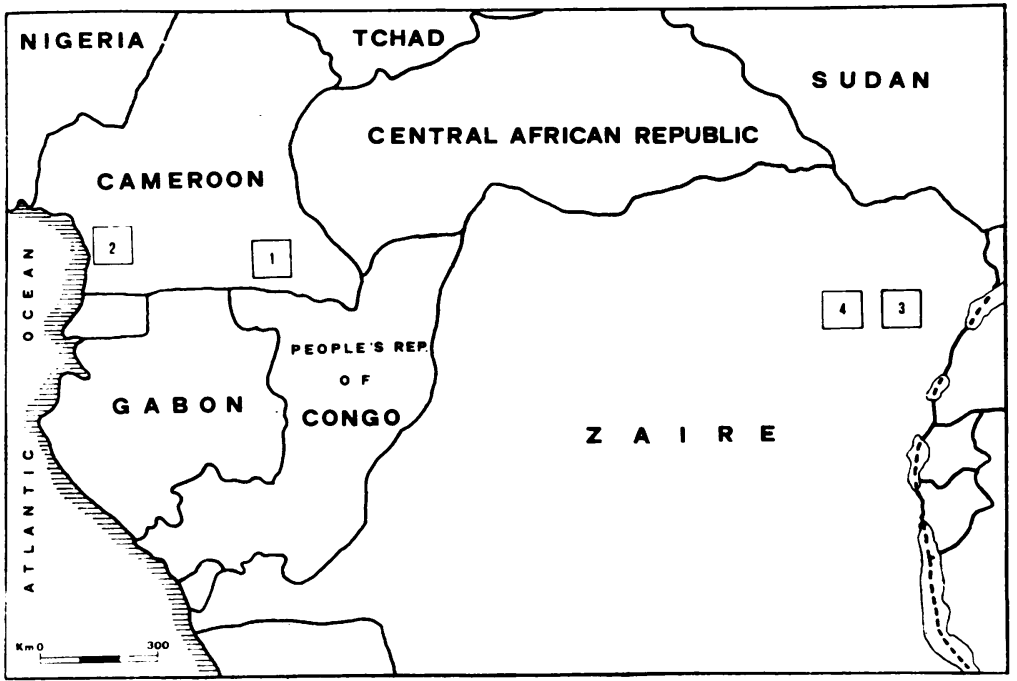

FIG. 1 Location of areas surveyed

(1) Lomié

(2) Akom-deux

(3) Epulu

(4) Bafuakoa 
territory of Mambasa. Clinical examinations were carried out by S.P. and specimens of blood taken for a multipurpose survey from a sample of the population. Adult patients with clinical yaws were treated with 1 mega unit procaine penicillin with aluminium monostearate (PAM); children were given 500,000 units. Supplies of PAM were left with nurses in the nearest villages with the recommendation that treatment should be repeated in 6 months' time; whether this was, in fact, done is not known. The immediate clinical response to treatment was very rapid.

\section{Serological tests}

Only small amounts of serum were available for examination at the V.D. Reference Laboratory. Many of these were turbid and unsuitable for flocculation or complementfixation tests. FTA-ABS and VDRL tests were carried out on all the sera by the standard techniques (PHLS Monograph, 1972), but in many instances no result could be obtained with the latter test because of the turbidity of the sera.

\section{Results}

\section{Clinical manifestation of yaws}

In the Cameroon, fifteen of 333 persons examined (4.5 per cent.) had clinical lesions of yaws. These comprised:

Early cutaneous and mucosal lesions
Osteoperiostitis
Gangosa
Late plantar hyperkeratoses
Depigmentation with scarring
Other late lesions

In Zaire, twenty of out 205 patients examined (10 per cent.) had lesions of yaws. These included:

Early ulcerated cutaneous and mucosal lesions 15

Late lesions with scarring

Osteoperiostitis

Ulcerated nodule

Depigmentation with scarring

2
1
1
1

Examples of these lesions are shown in Figs 2 to 5 . The early papillomatous lesions were all seen in children 3 to 8 years of age except in one case, a young adult about 14 years of age.

\section{Serological results}

The serological coverage of the camps visited is shown in Table I.

The discrepancy between the number of VDRL and FTA-ABS tests is due to the exclusion of

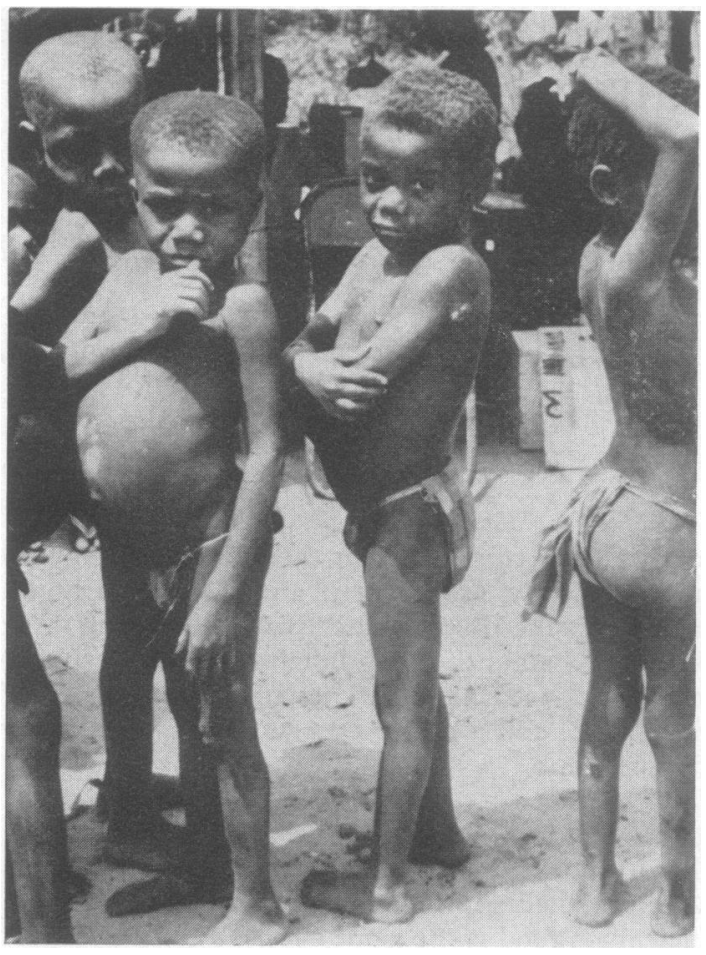

FIG. 2 Papillomatous framboesides

'unreadable' results with the former test because of turbidity of some of the sera.

\section{FTA-ABS TEST}

Reactivity of the FTA-ABS test in the different camps is shown in Table II and the distribution of reactivity by age in Tables III and IV.

VDRL TEST

The results of VDRL tests on persons in the various camps are shown in Table $\mathrm{V}$ and the age distribution of reactivity in Tables VI and VII.

\section{Discussion}

Unfortunately very few sera were available from children below the age of 12 years. The results of

TABLE I Serological coverage of camps surveyed

\begin{tabular}{|c|c|c|c|c|c|c|}
\hline Country & Area of camps & Population & \multicolumn{2}{|c|}{$V D R L$ tests } & \multicolumn{2}{|c|}{$F T A-A B S$ tests } \\
\hline \multirow[t]{2}{*}{ Cameroon } & $\begin{array}{l}\text { Lomié } \\
\text { Akom-deux }\end{array}$ & $\begin{array}{l}184 \\
149\end{array}$ & $\begin{array}{l}54 \\
20\end{array}$ & $\begin{array}{l}29 \\
13\end{array}$ & $\begin{array}{l}71 \\
22\end{array}$ & $\begin{array}{l}38 \\
15\end{array}$ \\
\hline & Total & 333 & 74 & 22 & 93 & 28 \\
\hline Zaire & $\begin{array}{l}\text { Epulu } \\
\text { Bafuakoa }\end{array}$ & $\begin{array}{r}160 \\
45\end{array}$ & $\begin{array}{l}84 \\
24\end{array}$ & $\begin{array}{l}52 \cdot 5 \\
53\end{array}$ & $\begin{array}{l}93 \\
30\end{array}$ & $\begin{array}{l}58 \\
67\end{array}$ \\
\hline
\end{tabular}




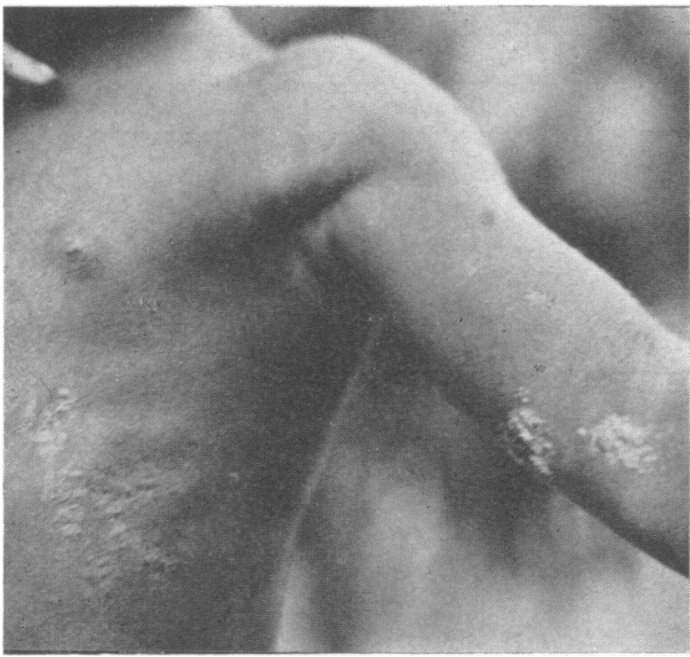

FIG. 3 Desquamative framboeside on the thorax and papillomatous lesions on the arm

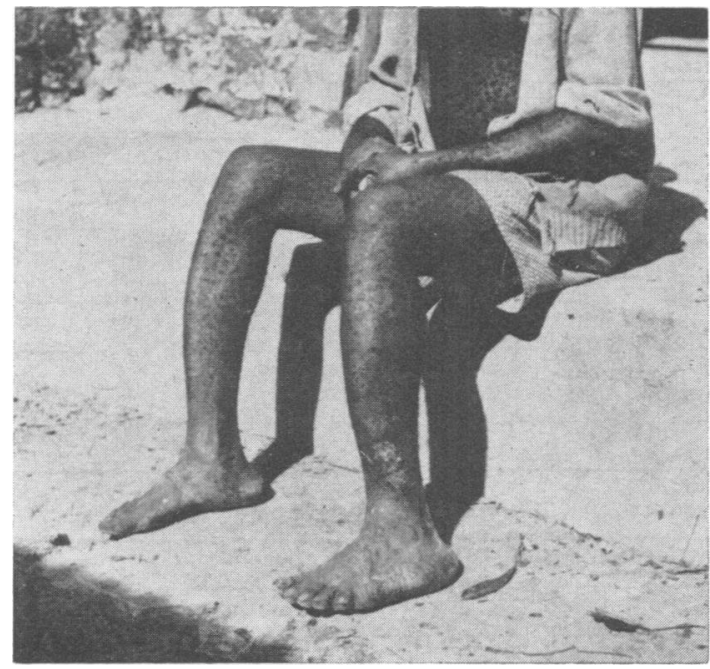

FIG. 4 Sabre tibiae

the FTA-ABS tests summarized in Tables III and IV show that in Cameroon two-thirds of the children

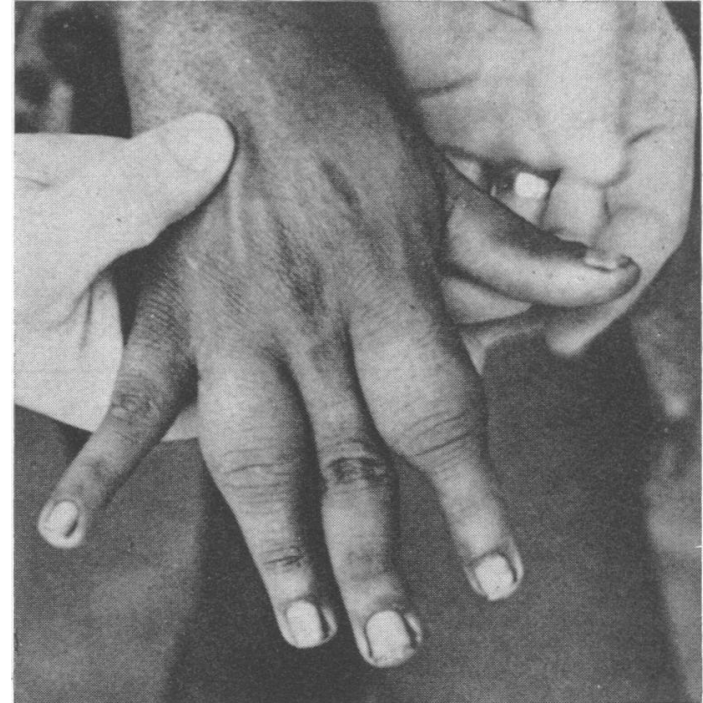

FIG. 5 Dactylitis

tested contracted treponemal infection by the time they reached the age of 12 years, and that thereafter the incidence of infection as judged by reactivity in the FTA-ABS test increased progressively until in the older age groups 80 to 90 per cent. of the population were affected. A similar pattern is evident from the survey in the camps in Zaire. All except one of the nine persons in the 13 to 20 -yr age group had reactive FTA-ABS tests.

Strongly reactive VDRL tests may be associated with the presence of infective lesions, or in latent infections, with the potentiality of infectious relapse (Guthe, 1969). The incidence of VDRL tests reactive at dilutions of 1 in 16 or above was considerably lower in the camps in Cameroon than among those in Zaire (Tables V and VI), expecially in the Bafuakoa area, where virtually all the VDRL results were of this titre. Early cutaneous or mucosal lesions were seen in three out of the 333 pygmies examined in Cameroon, but in fifteen out of the 205 examined in Zaire. Active transmission of yaws is obviously taking place in both areas but the situation is more serious among the pygmies in Zaire. False positive

TABLE II Prevalence of FTA-ABS reactivity in camps surveyed

\begin{tabular}{|c|c|c|c|c|}
\hline Country & Area & Sera tested & \multicolumn{2}{|c|}{$F T A-A B S$ reactive } \\
\hline \multirow[t]{2}{*}{ Cameroon } & $\begin{array}{l}\text { Lomié } \\
\text { Akom-deux }\end{array}$ & $\begin{array}{l}71 \\
22\end{array}$ & $\begin{array}{l}56 \\
18\end{array}$ & $\begin{array}{l}79 \\
82\end{array}$ \\
\hline & Total & 93 & 74 & $79 \cdot 5$ \\
\hline \multirow[t]{2}{*}{ Zaire } & $\begin{array}{l}\text { Epulu } \\
\text { Bafuakoa }\end{array}$ & $\begin{array}{l}93 \\
30\end{array}$ & $\begin{array}{l}79 \\
30\end{array}$ & $\begin{array}{r}85 \\
100\end{array}$ \\
\hline & Total & 123 & 109 & 88.5 \\
\hline
\end{tabular}


TABLE III FTA-ABS reactivity by age groups in Camps in Cameroon

\begin{tabular}{|c|c|c|c|c|c|}
\hline \multirow[b]{2}{*}{ Age (yrs) } & \multirow[b]{2}{*}{ Population } & \multirow[b]{2}{*}{ No. tested } & \multicolumn{3}{|c|}{$F T A-A B S$} \\
\hline & & & Negative & Doubtful & Positive \\
\hline $\begin{array}{c}0-2 \\
3-6 \\
7-12 \\
13-20 \\
21-30 \\
31-50 \\
>50\end{array}$ & $\begin{array}{l}17 \\
46 \\
70 \\
33 \\
58 \\
75 \\
34\end{array}$ & $\begin{array}{r}0 \\
1 \\
15 \\
16 \\
25 \\
25 \\
11\end{array}$ & $\begin{array}{l}-1 \\
3 \\
7 \\
5 \\
3 \\
-\end{array}$ & $\begin{array}{l}\frac{-}{2} \\
\frac{-}{7} \\
\frac{1}{1}\end{array}$ & $\begin{array}{r}- \\
10 \\
9 \\
20 \\
22 \\
10\end{array}$ \\
\hline Total & 333 & 93 & 19 & 3 & 71 \\
\hline
\end{tabular}

TABLE IV FTA-ABS reactivity by age groups in camps in Zaire

\begin{tabular}{|c|c|c|c|c|c|}
\hline \multirow[b]{2}{*}{ Age (yrs) } & \multirow[b]{2}{*}{ Population } & \multirow[b]{2}{*}{ No. tested } & \multicolumn{3}{|c|}{$F T A-A B S$} \\
\hline & & & Negative & Doubtful & Positive \\
\hline $\begin{array}{c}0-2 \\
3-6 \\
7-12 \\
13-20 \\
21-30 \\
31-50 \\
>50\end{array}$ & $\begin{array}{r}8 \\
25 \\
22 \\
19 \\
49 \\
65 \\
17\end{array}$ & $\begin{array}{r}0 \\
0 \\
1 \\
9 \\
43 \\
57 \\
13\end{array}$ & $\begin{array}{l}- \\
1 \\
1 \\
7 \\
4 \\
1\end{array}$ & $\begin{array}{l}\bar{z} \\
\overline{-} \\
\frac{4}{-}\end{array}$ & $\begin{array}{l}\overline{-} \\
- \\
8 \\
36 \\
49 \\
12\end{array}$ \\
\hline & 205 & 123 & 14 & 4 & 105 \\
\hline
\end{tabular}

TABLE $\mathrm{V}$ Reactivity in the VDRL test in the camps surveyed

\begin{tabular}{|c|c|c|c|c|c|c|}
\hline \multirow{3}{*}{ Country } & \multirow{3}{*}{ Area } & \multirow{3}{*}{ Sera tested } & \multicolumn{4}{|c|}{$V D R L$} \\
\hline & & & \multicolumn{2}{|c|}{ Reactive } & \multicolumn{2}{|c|}{ Reactive at titres $\overline{>} 16$} \\
\hline & & & No. & Per cent. & No. & Per cent \\
\hline \multirow[t]{2}{*}{ Cameroon } & $\begin{array}{l}\text { Lomié } \\
\text { Akom-deux }\end{array}$ & $\begin{array}{l}54 \\
20\end{array}$ & $\begin{array}{l}39 \\
17\end{array}$ & $\begin{array}{l}72 \\
85\end{array}$ & $\begin{array}{r}16 \\
4\end{array}$ & $\begin{array}{l}30 \\
20\end{array}$ \\
\hline & Total & 74 & 56 & 76 & 20 & 27 \\
\hline \multirow[t]{2}{*}{ Zaire } & $\begin{array}{l}\text { Epulu } \\
\text { Bafuakoa }\end{array}$ & $\begin{array}{l}84 \\
24\end{array}$ & $\begin{array}{l}68 \\
24\end{array}$ & $\begin{array}{r}81 \\
100\end{array}$ & $\begin{array}{l}41 \\
23\end{array}$ & $\begin{array}{l}49 \\
96\end{array}$ \\
\hline & Total & 108 & 92 & 85 & 64 & 59 \\
\hline
\end{tabular}

TABLE VI Distribution of VDRL reactivity by age groups in camps in Cameroon

\begin{tabular}{|c|c|c|c|c|c|}
\hline \multirow[b]{2}{*}{ Age (yrs) } & \multirow[b]{2}{*}{ Total population } & \multirow[b]{2}{*}{ No. tested } & \multicolumn{3}{|l|}{$V D R L$} \\
\hline & & & Negative & Reactive & Reactive $\overline{>} 16$ \\
\hline $0-2$ & 17 & 0 & - & - & - \\
\hline $3-6$ & 46 & 1 & 1 & - & - \\
\hline $7-12$ & 70 & 10 & 3 & 7 & 2 \\
\hline $13-20$ & 33 & 13 & 7 & 6 & 2 \\
\hline $21-30$ & 58 & 19 & 4 & 15 & 7 \\
\hline $31-50$ & 75 & 22 & 3 & 19 & 8 \\
\hline
\end{tabular}

VDRL results might have been anticipated considering the multiplicity of parasitic infections present in these populations; in fact, all the sera giving reactive VDRL tests were found to have reactive FTA-ABS tests.

\section{Summary}

In a survey of 333 pygmies in the Cameroon 4.5 per cent. were found to have clinical evidence of yaws.
This was also found in 10 per cent. of the inhabitants of camps in Zaire.

The results of VDRL and FTA-ABS tests on a sample of the population are presented. These provide evidence of a very high incidence of treponemal disease, 80 to 90 per cent. of the population showing serological evidence of infection. Active transmission is taking place in both areas but more frequently in Zaire. 
TABLE VII Distribution of VDRL reactivity by age groups in camps in Zaire

\begin{tabular}{|c|c|c|c|c|c|}
\hline Age (yrs) & Total population & No. tested & \multicolumn{3}{|l|}{$V D R L$} \\
\hline $\begin{array}{c}0-2 \\
3-6 \\
7-12 \\
13-20 \\
21-30 \\
31-50 \\
>50\end{array}$ & $\begin{array}{r}8 \\
25 \\
22 \\
19 \\
49 \\
65 \\
17\end{array}$ & $\begin{array}{r}0 \\
0 \\
0 \\
9 \\
38 \\
48 \\
13\end{array}$ & $\begin{array}{l}- \\
\bar{Z} \\
2 \\
8 \\
5 \\
1\end{array}$ & $\begin{array}{l}\overline{-} \\
\overline{7} \\
30 \\
43 \\
12\end{array}$ & $\begin{array}{r}- \\
\overline{-} \\
6 \\
23 \\
27 \\
8\end{array}$ \\
\hline Total & 205 & 108 & 16 & 92 & 64 \\
\hline
\end{tabular}

We wish to thank Prof. L. L. Cavalli Sforza, the Health Authorities of Cameroon, the Ministry of Health of Zaire (Dr. Kalonda), Mr. Biannic, Director of the Agence France Press in Yaoundé (Cameroon), Mrs. Biannic, and the Italian Ambassador in Cameroon, Mr. Marchetti, for their help.

The survey was supported by grants from the Italian National Research Council, The Wenner Gren Foundation, and the World Health Organization.

\section{References}

GuTHE, T. (1969) Acta derm.-venereol. (Stockh.), 49, 343

Pampligione, S., and Ricciardi, M. L. (1974) Riv. Parasitol. (in press)

Public Health Laboratory Service (1972) Monograph No. 1. 'Laboratory Diagnosis of Venereal Disease'. H.M.S.O., London

TURNBULL, C. (1965) 'Wayward Servants'. The Natural History Press, Garden City, N.Y. 